\title{
Levelling the Lake: Transboundary Resource Management in the Lake of the Woods Watershed
}

\author{
By Jamie Benidickson. 2019. University of British Columbia Press. 367 pages, 89.95 CAD, Cloth.
}

The Lake of the Woods watershed straddles the borders of Ontario, Manitoba, and Minnesota in the heart of the continent, providing a complex regional context for the examination of resource management issues of wider relevance. The watershed encompasses roughly $70000 \mathrm{~km}^{2}$, extending over $400 \mathrm{~km}$ from its outlet at the Winnipeg

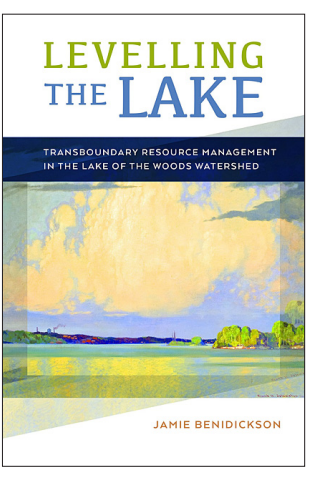
River near Kenora, Ontario, east to beyond Quetico Provincial Park and the Boundary Waters Canoe Area Wilderness. The broad geographic scope tackled by Levelling the Lake is matched by an ambitious time frame covering the last century and a half of resource management. Joining 30+ other titles in UBC Press' Nature/History/Society series, including his 2007 The Culture of Flushing: A Social and Legal History of Sewage, Jamie Benidickson's latest work explores the environmental, legal, and regulatory history of this vast area.

Although we pay little thought to the provincial boundaries today, as Benidickson chronicles, jurisdiction in this area was hotly disputed between the governments of Ontario and Canada in the latter part of the 19th century. This had profound effects on how natural resource extraction and development proceeded over the decades to come, and how the obligations of Treaty 3 were met (or not). For example, owing to the federal-provincial dispute, the delineation of reserves was not finalized until over four decades after the signing of Treaty 3 in 1873, during which time Indigenous communities lost prime agricultural lands they formerly used for their gardens. Indeed, an underlying current of broken treaty promises runs throughout the book and has one seriously questioning the "honour of the Sovereign" (p. 56).

Fourteen chapters examine how the various levels of government (e.g., federal, provincial, state, municipal) wrestled with often competing interests of hydroelectric development, forestry, mining, fishing, tourism, and recreation, as well as municipal development and agriculture. Although it makes for a complex story, Levelling the Lake benefits from its broad scope because so many component parts are intertwined, if only by their impacts on water quality and quantity. For example, the early timber industry in the watershed was particularly dependent on the hydropower required for its mills, and the control of flows and water levels facilitated log driving.

The strength of Levelling the Lake is its scholarship. Professor Benidickson teaches environmental law at the University of Ottawa, where he is a highly respected member of the Centre for Environmental Law and Global Sustainability. Not surprisingly, Levelling the Lake is impressively researched, and provides 66 pages of endnotes, as well as suggested readings and an index. The maps are effective despite the lack of colour, and essential for orienting the reader. I found the 19 historical photos a treat, particularly for familiar locales, and wished there had been more. The inclusion of graphic timelines or additional charts might have helped readers hang on to the narrative thread when at times it is difficult to navigate the maze of names and dates. Fortunately, Benidickson (largely) manages to render complicated subject matter comprehensible, typically with a deft or wry turn of phrase. For example, when discussing the impossibility of securing both uniform level and uniform outflow on Lake of the Woods, the author remarks, "Anyone likely to confuse management of a large watershed with filling a bathtub was thus on notice to expect disappointment" (p. 11).

Levelling the Lake reminds us that history is very much alive and provides some cautionary tales. The Lake of the Woods Rainy River sturgeon (Acipenser fulvescens) populations that crashed a century ago from overfishing and habitat degradation have still not recovered. Historical mercury contamination in the English-Wabigoon River system from a pulp mill near Dryden continues to have devastating impacts on downstream Indigenous communities. The enormous pit at the former Steep Rock Iron Mine near Atikokan continues to fill with water and without mitigation will eventually overflow, risking potential downstream effects (in 1951, turbidity from the site reached as far as Fort Frances!). Yet, Benidickson also provides some positive examples of mechanisms enabling a more sustainable approach to water management, such as the International Joint Commission (IJC) and the world-renowned Experimental Lakes Area (ELA) research program.

Levelling the Lake provided a new lens through which to view my backyard, from lesser-known events like the misguided expulsion of the Sturgeon Lake Indian Band from Quetico Provincial Park to 
broader themes of our role in resource stewardship. ties, and Indigenous studies, not to mention resource This book will similarly appeal to anyone with a strong interest in environmental history, particularly students and scholars of the social sciences, humanimanagers in this neck of the woods and beyond.

ROBERT F. FOSTER Northern Bioscience, Thunder Bay, ON, Canada (C) The author. This work is freely available under the Creative Commons Attribution 4.0 International license (CC BY 4.0). 